\title{
OPEN A fast-growing basal troodontid (Dinosauria: Theropoda) from the latest Cretaceous of Europe
}

\begin{abstract}
Albert G. Sellés ${ }^{1,2 \bowtie}$, Bernat Vila ${ }^{1,2}$, Stephen L. Brusatte ${ }^{3}$, Philip J. Currie ${ }^{4}$ \& Àngel Galobartt ${ }^{1,2}$
A characteristic fauna of dinosaurs and other vertebrates inhabited the end-Cretaceous European archipelago, some of which were dwarves or had other unusual features likely related to their insular habitats. Little is known, however, about the contemporary theropod dinosaurs, as they are represented mostly by teeth or other fragmentary fossils. A new isolated theropod metatarsal II, from the latest Maastrichtian of Spain (within 200,000 years of the mass extinction) may represent a jinfengopterygine troodontid, the first reported from Europe. Comparisons with other theropods and phylogenetic analyses reveal an autapomorphic foramen that distinguishes it from all other troodontids, supporting its identification as a new genus and species, Tamarro insperatus. Bone histology shows that it was an actively growing subadult when it died but may have had a growth pattern in which it grew rapidly in early ontogeny and attained a subadult size quickly. We hypothesize that it could have migrated from Asia to reach the Ibero-Armorican island no later than Cenomanian or during the Maastrichtian dispersal events.
\end{abstract}

During the latest Cretaceous (ca. 77-66 million years ago) in the run-up to the end-Cretaceous mass extinction, Europe was a series of islands populated by diverse and distinctive communities of dinosaurs and other vertebrates. Many of these animals exhibited peculiar features that may have been generated by lack of space and resources in their insular habitats. These include dwarf sauropod and ornithischian dinosaurs with slow growth rates $^{1-4}$, anatomically bizarre small theropods ${ }^{5,6}$, and mammals with reduced brain sizes ${ }^{7}$. Furthermore, these faunas were notably different from those on the closest mainlands (Asia and North America). The characteristic European 'island fauna' consisted of titanosaurian sauropods, rhabdodontid iguanodontians, nodosaurid ankylosaurians, basal hadrosauroids, lambeosaurine hadrosauroids, and some abelisauroid and maniraptoran theropods ${ }^{8,9}$. As more fossils of these animals are discovered, they are becoming increasingly important for understanding how dinosaurs and other vertebrates changed before the end-Cretaceous asteroid impact, and for testing hypotheses of rapid ${ }^{10}$ vs. gradual extinction ${ }^{8,11}$.

There are still large gaps in our understanding of these island faunas, in terms of their composition and their evolution over time. Relatively little is known about the theropod dinosaurs, which were the top predators on the mainland during this time, and probably also on the islands (although they may have shared this role with gigantic pterosaurs ${ }^{12}$ ). Theropods also diversified into omnivorous and herbivorous species ${ }^{13}$. Based on what is currently known, the non-avian theropod faunas were dominated by small-sized ( $<50 \mathrm{~kg})$ dromaeosaurids, whose fossils have been found in latest Cretaceous (Campanian and Maastrichtian) formations of the so-called Ibero-Armorican region (including the current areas of Portugal, Spain, and southern France), and in Transylvania (Romania) $)^{5,8,9,14,15}$. Frustratingly, they are nearly exclusively represented by isolated teeth ${ }^{14}$ and eggshell fragments ${ }^{15-17}$. Skeletal remains are extremely scarce ${ }^{18-21}$. Some exceptions include the partial skeleton of Balaur bondoc $^{5,6}$ and the more fragmentary specimens of Pyroraptor olympius $\mathrm{s}^{22,23}$ and Variraptor mechinorum ${ }^{20-23}$

Knowing more about the island-dwelling theropods would provide considerable insight into the paleoecology and paleobiogeography of these insular ecosystems ${ }^{8}$. During the terminal Cretaceous, several paleogeographic, climatic, and biotic changes occurred worldwide ${ }^{24-28}$. In the European archipelago, there was a turnover amongst the dinosaur faunas in the 'middle' Maastrichtian'. Perhaps related to some of these changes, nodosaurids

${ }^{1}$ Institut Català de Paleontologia Miquel Crusafon, Edifici Z, C/ de les columnes s/n, Campus de la Universitat Autònoma de Barcelona, Cerdanyola del Vallès, Barcelona, Spain. ${ }^{2}$ Museu de la Conca Dellà, 25650 Lleida, Isona, Spain. ${ }^{3}$ School of GeoSciences, University of Edinburgh, Edinburgh EH9 3FE, UK. ${ }^{4}$ University of Alberta, CW-405 Biological Sciences Building, Edmonton, AB T6G 2E9, Canada. ${ }^{\varpi}$ email: albert.garcia@icp.cat 


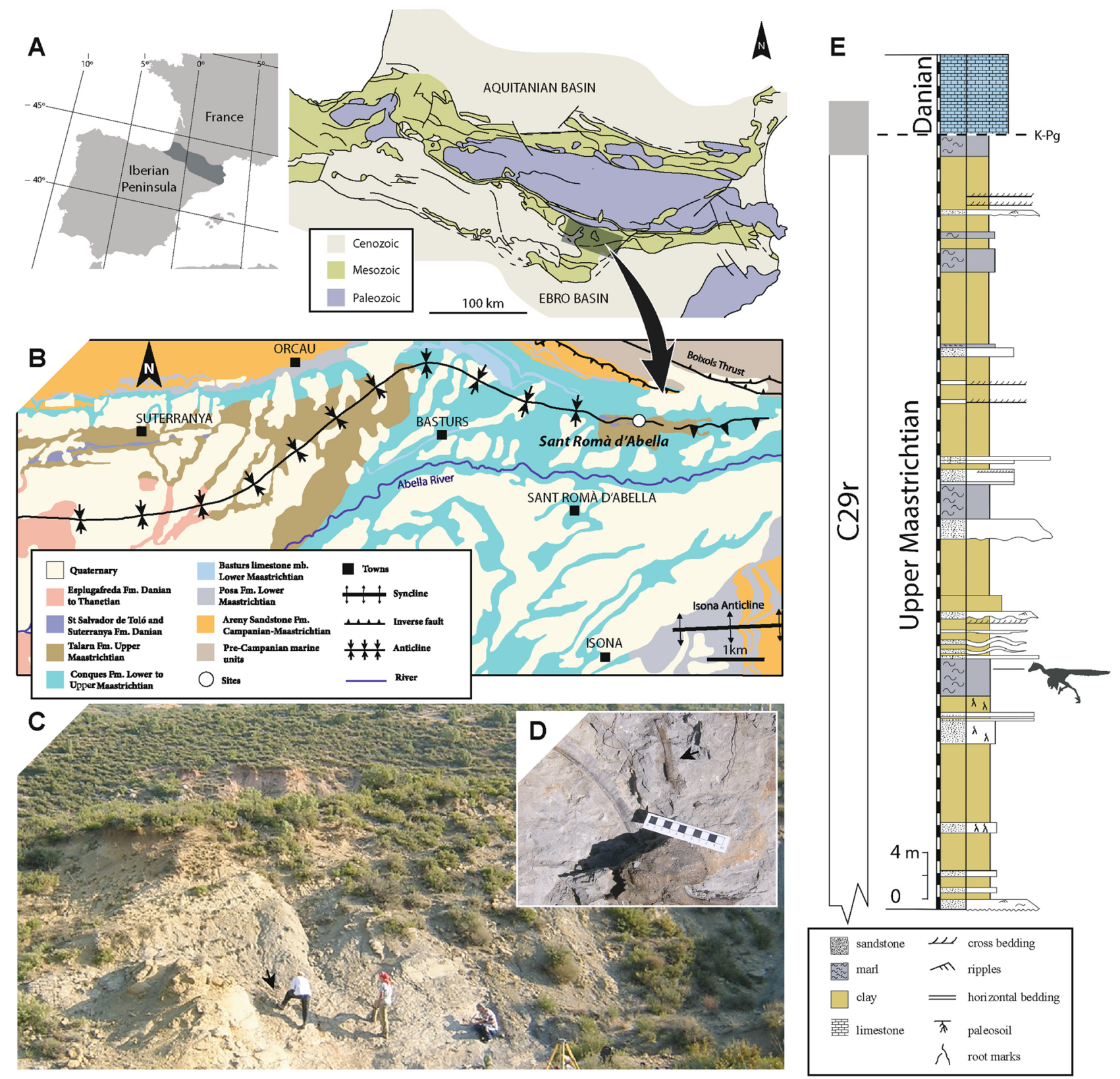

Figure 1. Geographic and geological location of Sant Romà d'Abella site. Geographic location of the Tremp Syncline in the southern Pyrenean region (A). Geological map of the eastern part of the Tremp Syncline with the location of the Sant Romà d'Abella site (B). Landscape view of the fossil site $(\mathbf{C})$ with a detailed picture showing the close spatial relationship between the troodontid metatarsal (MCD-7073) and axial elements of Pararhabdodon isonensis (D). Stratigraphic section at Sant Romà d'Abella area with the precise position of the fossiliferous Sant Romà d'Abella site $(\mathbf{E})$.

disappeared and more primitive rhabdodontids gave way to larger and more derived hadrosauroids ${ }^{9,29}$. It is unclear, however, whether theropods were affected by turnover. It is also uncertain where the theropods of the Ibero-Armorican land mass ultimately came from, and whether they were island dwarves or otherwise affected by their island habitat. Any new theropod fossils have the potential to shed light on these issues.

We here describe a newly discovered theropod bone from the very end of the Cretaceous (within 200,000 years of the mass extinction) of the Ibero-Armorican island. Its unique combination of anatomical characters allows its identification as a new species. Furthermore, its histology shows a growth pattern in which it grew fast in early ontogeny but reached subadult size quickly. The new species appeared within the faunal turnover on the island in the early Maastrichtian, which helps define the origins and timings of the migratory waves that brought the newcomers to the European archipelago.

The specimen was discovered in September 2003 by a team of palaeontologists from the Museu de la Conca Dellà (MCD) at the Sant Romà d'Abella site (Fig. 1). According to the most recent stratigraphic data ${ }^{15}$, the Sant 
Romà d'Abella site falls within the upper part of the fluvial Talarn Formation of the Tremp Group (Fig. 1B). The fossil-bearing horizon of the Sant Romà d'Abella site is located in a 1.5-m-thick greyish marl layer (Fig. 1C), which is part of a $18 \mathrm{~m}$-thick sedimentary sequence related to the development of a fluvial floodplain ${ }^{30}$. The fossiliferous horizon has yielded abundant plant remains, and the type specimen of the tsintaosaurin lambeosaurine Pararhabdodon isonensis ${ }^{31-33}$. The theropod specimen was found a few decimetres from bones of P. isonensis (Fig. 1D) and is the only other vertebrate remain in the site. Based on magnetostratigraphic, and biochronologic calibrations, the Sant Romà d'Abella site falls within the C29r magnetochron (latest Maastrichtian), thus placing the site within the final 200 ka before the K-Pg boundary ${ }^{15}$ (Fig. 1E).

\section{Results \\ Systematic palaeontology. Dinosauria Owen, 1842}

Theropoda Marsh, 1881

Coelurosauria Huene, 1914

Maniraptora Gauthier, 1986

Troodontidae Gilmore 1924

? Jinfengopteryginae Turner, Makovicky, and Norell2012

Tamarro insperatus gen. et sp. nov.

urn:lsid:zoobank.org:act:ADDD1AB2-BC87-4A17-A5D9-78B42B29AAD2

urn:lsid:zoobank.org:act:88919F32-2AE8-4587-AB8F-5D5852FA7FF5

Etymology. Tamarro, Catalan word referring to a small and elusive fantastic creature from the regional (Pallars county) folklore. Insperatus, from the Latin word for "unexpected", in reference to the unexpected discovery of the specimen.

Holotype MCD-7073, a partial right metatarsal II (Fig. 2).

Diagnosis Tamarro insperatus is a mid-sized basal troodontid distinguished by the following unique combination of characters ( ${ }^{*}$ marks potential autapomorphies): metatarsal II with marked plantar ridge; small foramen on the lateral surface of the plantar ridge of the metatarsal II*; sub-arctometatarsalian condition with the metatarsal III restricted to the plantar margin on its proximal part.

Type locality and age Sant Romà d'Abella locality (Pallars Jussà, Catalonia); upper part of the Talarn Formation of the Tremp Group. The site is correlated with the C29r magnetochron ${ }^{14}$, latest Maastrichtian age.

Nomenclatural acts: The electronic version of this article in Portable Document Format (PDF) will represent a published work according to the International Commission on Zoological Nomenclature (ICZN), and hence the new names contained in the electronic version are effectively published under that Code from the electronic edition alone. This published work and the nomenclatural acts it contains have been registered in ZooBank, the online registration system for the ICZN. The ZooBank LSIDs (Life Science Identifiers) can be resolved and the associated information viewed through any standard web browser by appending the LSID to the prefix http://zoobank.org/. The LSID for this publication is: [urn:lsid:zoobank.org:pub:4EA36DCA-EF96-4826-8167BCF1357FE445]. The online version of this work is archived and available from the following digital repositories: PubMed Central and CLOCKSS.

Description. MCD-7073 is a right metatarsal II that lacks its proximal end (Fig. 2). Its bone surface is textured with a pattern of interweaving striations oriented parallel to the long axis of the element. In anterior view (Fig. 2A), it has a long, slender, and nearly straight diaphysis, which is moderately constrained mediolaterally on its distal half. While the lateral surface of the bone remains nearly straight and flat, the medial one is slightly convex and bows medially to the distal end. At shaft mid-length, the cross-section of the metatarsal is mediolaterally compressed to oval in shape, with the long axis oriented anteroposteriorly (Fig. 2E). The distal articulation facet is asymmetrical and inclined mediolaterally relative to the long axis of the shaft. This geometric configuration is produced by the differential proximodistal development of the distal condyles, in which the lateral one is larger than the medial one. The anterior surface of the distal articulation lacks the characteristic extensor sulcus of a ginglymoid joint. Instead, the medial and lateral condyles are connected anteriorly by a convex surface (Fig. 2A,H) textured with longitudinal striations. A subtle rugose lip is located on the lateral margin of the distal end of the metatarsal, which is here interpreted as the anterodistal contact with the metatarsal III (Fig. 2F). This structure indicates that the third metatarsal partially covered the anterior surface of the metatarsal II.

Laterally, the shaft of the metatarsal increases gradually in its depth distally until the mid-length of the diaphysis where it begins to taper towards the distal end. This results in a posteromedial ridge that occupies almost half of the preserved length. As a consequence, a posterolaterally-facing facet is exposed along the posterior side of the autopodium (Fig. 2B). A small foramen is observed adjacent to the upper part of the posteromedial ridge. The lateral surface of the metatarsal II possesses a smooth facet for articulation with the medial surface of the metatarsal III (Fig. 2B). This surface originates near the proximodistal side of the shaft as a shallow concave facet that quickly tapers distally above the level of the proximal end of the posteromedial ridge. Then, it continues as a narrow flat surface almost to the level of the nutritional foramen, when it expands anteroposteriorly until reaching the lateral condyle of the distal articulation (Fig. 2B). Near the distal end, a small posterolaterallydirected, oval facet is located between the posterior edge of the articular surface for the metatarsal III and the plantar ridge. This low-relief surface is interpreted as the posterior contact between the second and the fourth metatarsals (Fig. 2F). The distal articulation is well developed posteriorly, and there is an enlarged and deep collateral ligament fossa. In medial view, the metatarsal is slightly crescentic in shape, mainly because of the anteroposterior development of the posteromedial ridge. The medial collateral ligament fossa is well developed, having a teardrop-like shape, but it is smaller and shallower than the lateral ligament fossa. 

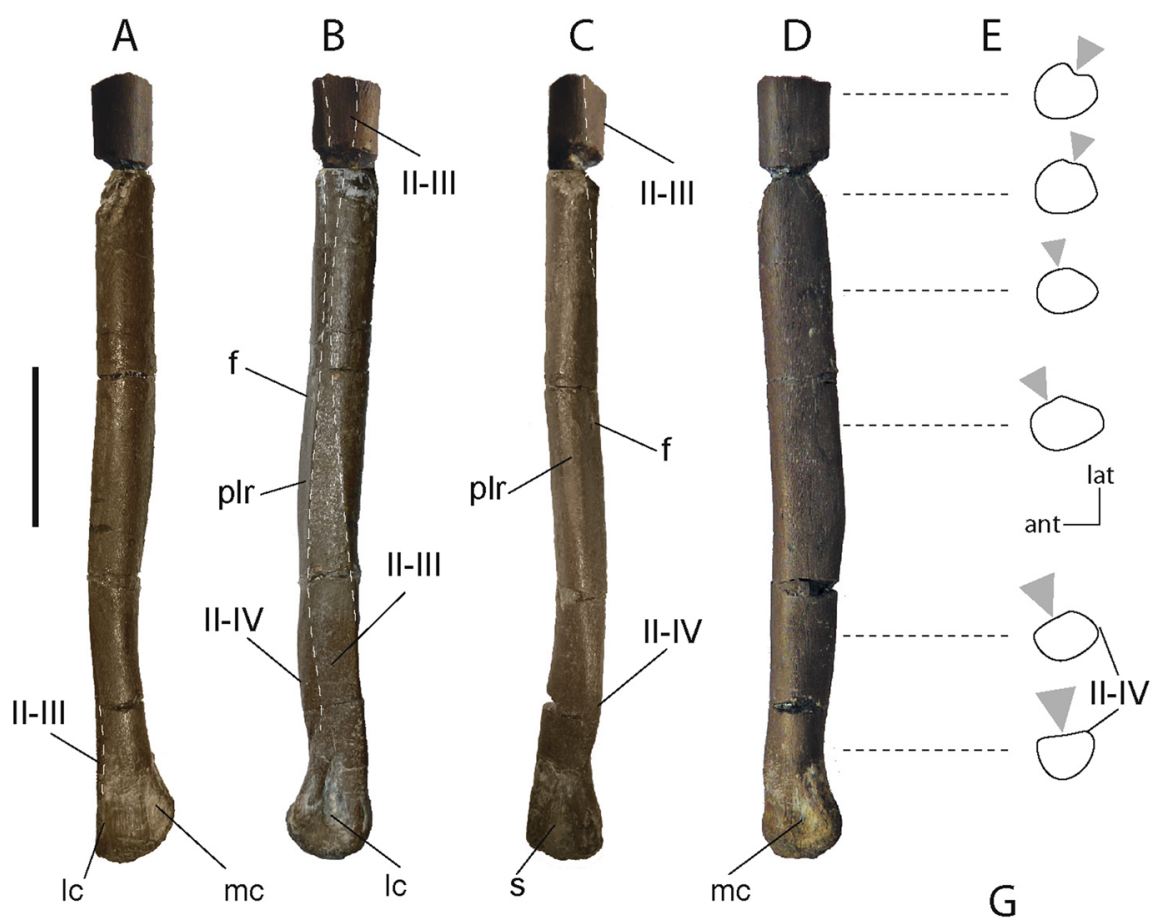

$\mathrm{F}$
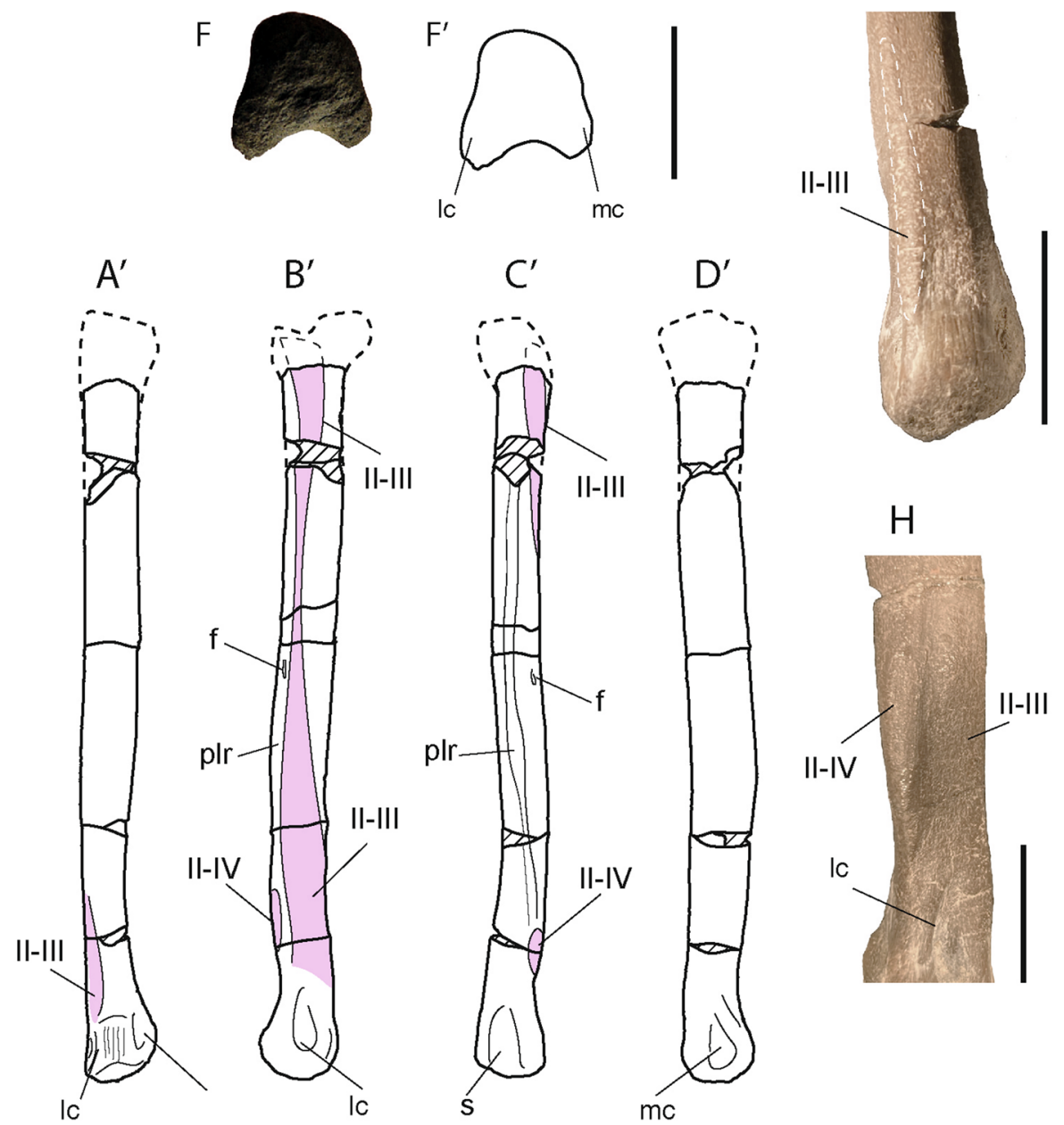

Figure 2. The European troodontid Tamarro insperatus (MCD-7073) gen. et sp. nov. from the uppermost Maastrichtian of the Tremp Group, Tremp Basin, Southern Pyrenees. Photographic and interpretative ilustrations of the right second metatarsal in anterior $\left(\mathbf{A}-\mathbf{A}^{\prime}\right)$, lateral (B-B'), posterior (C-C'), medial (D-D'), and distal (F-F') views. Scheme illustrating the gradual transition of the articular surface-grey arrow-for the accommodation of the metatarsal III (E). Detail of the distal end of the metatarsal II in anterior view showing the anterior contact surface of the metatarsal III (G). Detail of the articular surface of the metatarsal IV in the posterodistal part of the second metatarsal $(\mathbf{H})$ ant anterior; $f$ foramen; lat lateral; $l c$ medial condyle; $m c$, lateral condyle; II-III contact between the second and third metatarsals; II-IV contact between the second and fourth metatarsals; plr plantar ridge; $s$ sulcus. 
The metatarsal is straight in posterior view (Fig. 2C), disrupted medially only by the edge of the posteromedial ridge, and distally by the medial deflection of the medial condyle. In this view, the facet for the metatarsal III twists from the mid-shaft of the bone toward the proximal end, and the articular surface for metatarsal is well exposed in the distal part of the bone (Fig. 2F). The distal articular surface is characterized by a deep flexor grove that separated the distal condyles. The articular facet for the metatarsal-phalangeal joint is markedly rounded anteriorly and concave posteriorly, bestowing a rounded horseshoe-like shape in distal view (Fig. $2 \mathrm{H})$.

Comparisons. Several taxa of small-sized theropods have been described from the upper Cretaceous formations of southwestern Europe, including the deinonychosaurians Pyroraptor and Richardoestesia, the enigmatic Paronychodon, and indeterminate velociraptorines ${ }^{14}$, all of which are represented by highly fragmentary remains, in some cases solely teeth. Other small theropods, notably the dromaeosaurid Balaur ${ }^{5,6}$ and the enigmatic Elopteryx ${ }^{34,35}$, Heptasteornis ${ }^{36}$, and Bradycneme ${ }^{37}$ are known from similar-aged deposits in south-eastern Europe (Romania). Balaur is represented by a relatively complete, associated, and well-preserved holotype skeleton, which provides the best glimpse at the anatomy of a latest Cretaceous European theropod ${ }^{5,6}$.

The second metatarsal from Sant Romà d'Abella (MCD-7073) can be compared to these, and other, smallbodied Cretaceous theropods. Although fragmentary, this metatarsal exhibits a series of distinctive anatomical features that allow us to assess its taxonomic affinity. These key features are: (1) the lack of a distal ginglymoid joint, (2) a sub-arctometatarsalian condition, (3) the straightness of the distal end (unbowed medial margin), (4) distal constriction of the shaft, (5) small distal articular joint with a horseshoe-like outline in distal view.

First, MCD-7073 lacks the characteristic ginglymoid joint end, which is considered an unequivocal dromaeosaurid synapomorphy, present even in the most basal members of the group, including in the European Pyroraptor olympius ${ }^{23}$. Only a few dromaeosaurids, such as Imperobator ${ }^{38,39}$, the unenlagiid Neuquenraptor ${ }^{40}$, and the microraptorine Zhongjianosaurus ${ }^{41}$, lack or show a very poorly developed ginglymus in $\mathrm{Mt} \mathrm{II}^{24}$. Metatarsal II is also not ginglymoid in Balaur ${ }^{5,6}$ (but some authors disagree with the dromaeosaurid affinities of Balaur ${ }^{42}$ ). Although it cannot be completely ruled out that MCD-7073 is a rare and unusual dromaeosaurid without a ginglymoid metatarsal II, we consider this unlikely. Even if it was an aberrant dromaeosaurid, MCD-7073 could be distinguished from the contemporaneous European dromaeosaurid Pyroraptor olympius in that the second metatarsal of the latter is characterized by a concave posterior margin ${ }^{22,23}$, a feature not present in MCD-7073. Additionally, MCD-7073 is strikingly different from Balaur, which has much shorter and more robust metatarsals that are covered with bizarre textures ${ }^{5,6}$. Accordingly, and primarily based on the lack of a ginglymoid articulation, the second metatarsal from Sant Romà d'Abella cannot be confidently attributed to a dromaeosaurid deinonychosaurian.

The anatomical relationship between metatarsals II and III within the metatarsus can be inferred by scrutinizing the morphology of the interosseous contact along the lateral surface of MCD-7073. As described, the articular surface for the accommodation of the third metatarsal on the shaft of the second one extends from the posteroproximal to the anterodistal side of the lateral side, increasing its depth distally (Fig. 2B). This configuration indicates that the third metatarsal was posteriorly displaced near the proximal end of the metatarsus -but not necessarily excluded from the anterior face- whereas it was clearly exposed from the mid-length to the distal part of the tarsometatarsus. The preserved proximal part of MCD-7073 is laterally concave and further indicates that the medial margin of the proximal end of metatarsal III was convex, and not reduced to a thin bar of bone (Fig. 2E). Besides, the occurrence of a distal articular facet for metatarsals II-IV contact in the posterodistal part of MCD-7017 (Fig. 2G) suggests that metatarsal III was forced to reduce its contribution to the posterodistal surface of the pes. Overall, this anatomical arrangement resembles the sub-arctometatarsalia exhibited by basal troodontids (i.e. Sinovenator changii, Sinornithoides youngi, and MPC-D 100/140) ${ }^{43,44}$, and caenagnathid oviraptorosaurians (i.e. Elmisaurus rarus and Citipes elegans) ${ }^{45}$; but differs from the arctometatarsalian morphology of derived ornithomimosaurians and the hyper-arctometatarsalian nature of parvicursorine alvarezsaurians ${ }^{43,46,47}$. On the other hand, basal alvarezsaurians display the plesiomorphic condition on the arrangement of the metatarsals, and only Achillesaurus and Alnashetri show third metatarsals slightly appressed between metatarsals II and IV, but not restricted to the ventral part of the shaft as in MCD-7073 (see Fig. S1).

One of the most salient features of MCD-7073 is the straightness of the lateral side of the shaft, especially on its distal end. As observed in MCD-7073, the lateral condyle remains unbowed regarding the long axis of the metatarsal, while the medial one is medially deflected. This arrangement in the orientation of the distal condyles is present in troodontids (i.e. Talos, Latinevenatrix, Philovenator) ${ }^{48-50}$ and caenagnathids ${ }^{45}$, but differs from

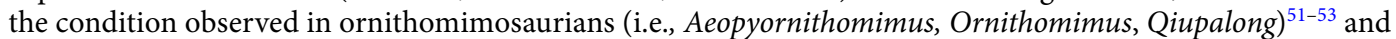
avimimids ${ }^{54}$, where the two distal condyles are medially tilted due to the mediolateral bowing of the distal fifth of the diaphysis of metatarsal II. In addition, most of derived alvarezsaurids have straight distal epiphyses (i.e. Alvarezsaurus, Kol, Parvicursor, Nemegtonykus), which resemble the condition of MCD-7073. But alvarezsaurids lack the medial deflection of the medial distal condyle and the constriction of the distal end that exhibits the studied specimen. Furthermore, as above stated, they also differ from MCD-7073 in the anatomical relationship of metatarsals (hyper-arctometatarsalia). Because of that, it seems unlikely that MCD-7073 could be referred to this particular group of maniraptorans (see Fig. S1).

MCD-7073 shows a marked anteroposterior development on its mid-shaft, resulting in a posteromedial plantar ridge. This ridge is an uncommon feature among coelurosaurs generally, and when it is present, it is usually not as developed as in MCD-7073. Caenagnathids are distinguished by strong and well-developed posterior ridges on both Mt II and Mt IV ${ }^{45}$, which are more developed and more distally located on the shafts than in MCD7073. In part, the different location of the plantar ridge is enabled by the occurrence of a marked mediolateral constriction in the distal part of the diaphysis of MCD-7073, just above the distal condyles. In caenagnathids, the mediolateral width remains nearly invariable along the shaft, thus bestowing a more robust aspect to the 


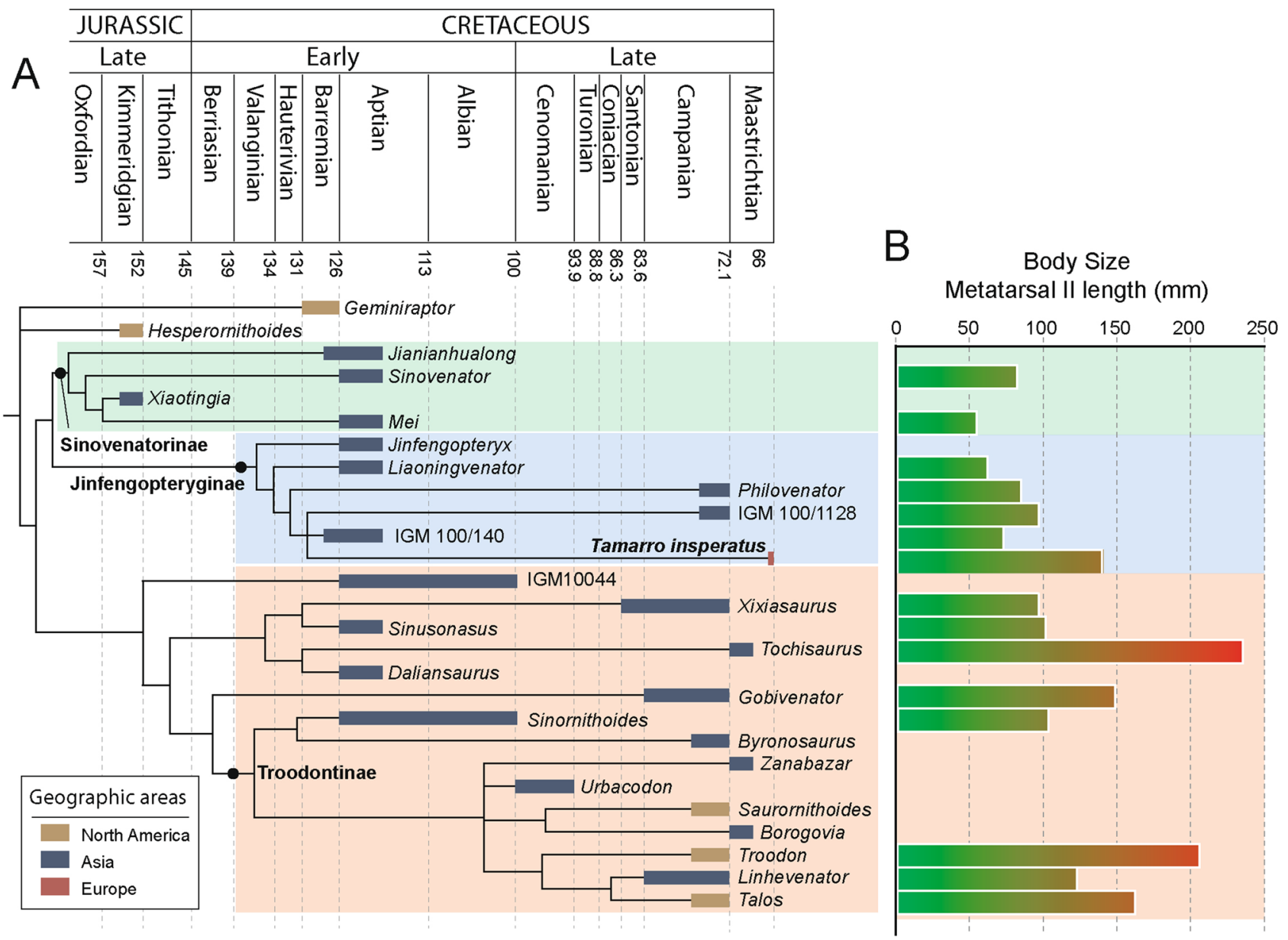

Figure 3. Phylogenetic relationships of Tamarro insperatus (MCD-7073) gen. et sp. nov. Simplified timecalibrate topology of the strict consensus phylogenetic trees (CI: 0.073, RI: 0.615) of 10 most parsimonious trees of 13,064 steps (A), and the evolution of body size using the length of the metatarsal II as a proxy (B). Additional data available in the Supplementary Table S2.

second metatarsal than in MCD-7073. In addition, MCD-7073 differs from this family of oviraptorosaurians in the morphology of the distal articulation, which is rounded and nearly spherical in caenagnathids ${ }^{45}$, while it is horseshoe-shaped in MCD-7073 (see Fig. S1).

A posteromedial ridge on the second metatarsal is observed in some basal troodontids ${ }^{44,50,55,56}$, while in more derived taxa that have very thin second metatarsals, the posterior ridge is reduced ${ }^{48,49,57}$. In this regard, MCD7073 resembles the basal condition within Troodontidae. Finally, the reduced size of the metatarsal II, relative to metatarsals III and IV, is characteristic of most troodontids. This constriction is not restricted to the diaphysis, but also to the distal articulation. As a consequence, in distal view, the articular surface of the distal joint is anteroposteriorly deeper than mediolaterally wide, giving it a horseshoe-shape as in MCD-7073 (see Fig. S1).

Summarizing these comparisons, MCD-7073 shares features with basal troodontids (straight shaft, sub-arctometatarsalian morphology, unbowed distal end, horseshoe-shaped distal articulation), and has notable differences with other clades of Cretaceous small theropods. Additionally, MCD-7073 possesses a potential autapomorphic feature not reported in any other troodontid, the occurrence of a nutritional foramen on the posteromedial surface of the second metatarsal, which supports its designation as a new taxon, Tamarro insperatus gen. et. sp. nov. urn:lsid:zoobank.org:act:ADDD1AB2-BC87-4A17-A5D9-78B42B29AAD2

urn:Isid:zoobank.org:act:88919F32-2AE8-4587-AB8F-5D5852FA7FF5

Phylogenetic results. Our broad-scale coelurosaurian phylogenetic analysis based on Hartman et al. ${ }^{58}$ yielded 10 most parsimonious trees (MPTs) of 13,064 steps, with a consistency index (CI) of 0.073 and a retention index (RI) of 0.615 . The strict consensus tree returned a well-resolved topology in which Tamarro insperatus was recovered in a polytomic relationship with the Mongolian troodontids MPC-D 100/1128 (sometimes referred as MPC-D 100/1126) and MPC-D 100/140 (Fig. 3). These three taxa are the most derived members of a group where Jinfengopteryx, Liaoningvenator, and Philovenator are recovered as consecutive taxa. This taxonomic grouping resembles that of Jinfengopteryginae defined by Turner et al. ${ }^{23}$. The identification of Tamarro as a jinfengopterygine seems to be supported by the plantar displacement of metatarsal III at its proximal end relative to the positions of metatarsals II and IV, a synapomorphic feature of this group of troodontids ${ }^{23}$. 

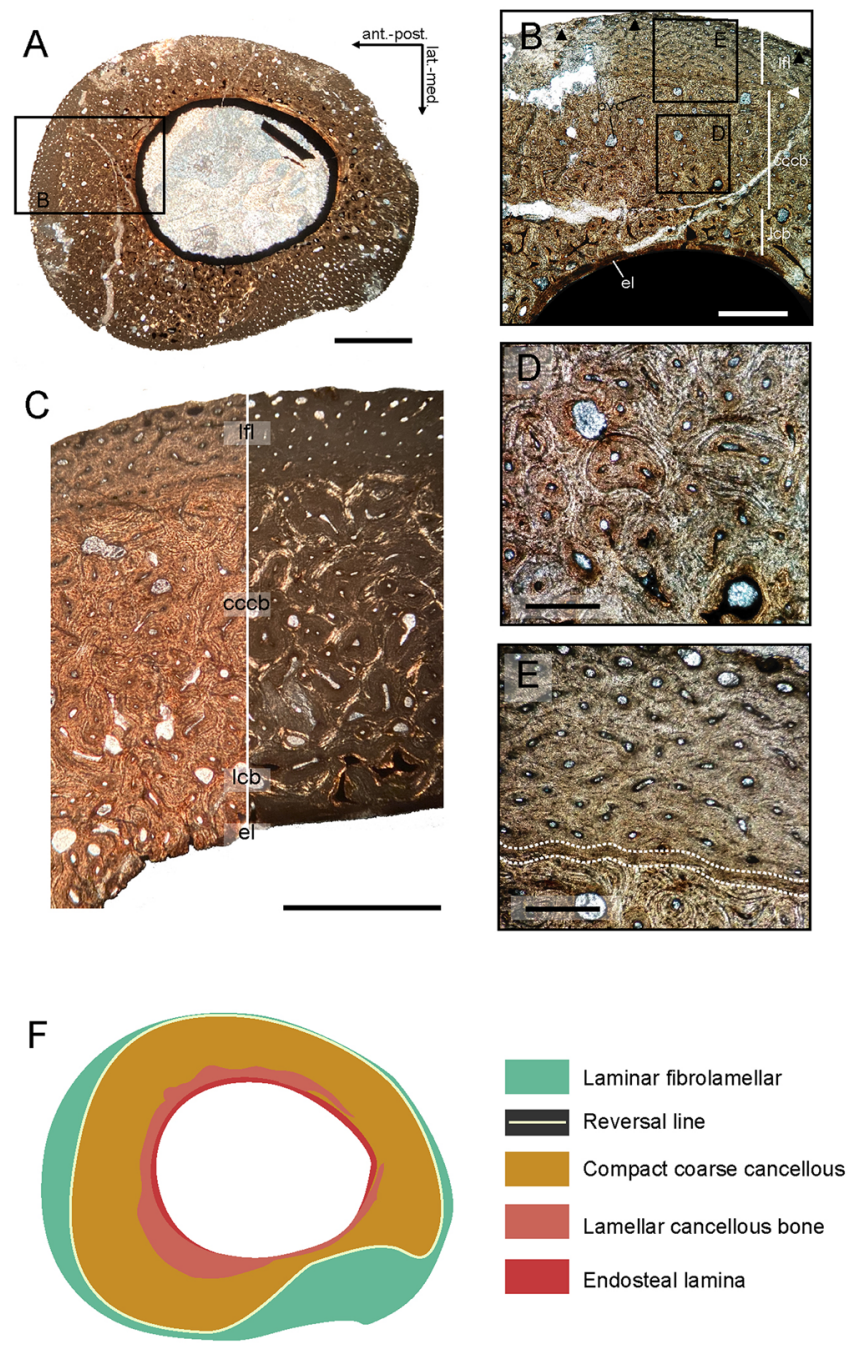

Figure 4. Osteohistology of Tamarro insperatus gen. et sp. nov. based on the osteohistological sample from the metatarsal II (MCD-7073). Full petrographic transverse thin section from the proximal mid-shaft of the Mt II (A). Detail of the cortex showing the predominance of primary lamellar and fibrolamellar bone tissues. Black arrows indicate the location of a LAG. White arrow shows the location of the reversal line (B). Outer cortex under transferred and polarized light displaying the distinctive arrangement of the bone tissues $(\mathbf{C})$. Magnification of the inner cortex showing the infilling of primary cancellous spaces with lamellar bone (D). Osteohistological transition (white dashed lines) between the compact coarse cancellous bone of the inner cortex and the laminar fibrolamellar of the outer cortex (E). Type tissue map of areas representing different tissue types are colour coded for quantitative analyses (F). cccb compact coarse cancellous bone; $e$ endosteal lamina; $l c b$ lamellar cancellous bone; $l f l$ laminar fibrolamellar; $p v c$ primary vascular canal. Scale bar: $2 \mathrm{~cm}(\mathbf{A})$, $0.5 \mathrm{~mm}(\mathbf{B}), 1 \mathrm{~cm}(\mathbf{C})$, and $0.2 \mathrm{~mm}(\mathbf{D}, \mathbf{E})$.

Our phylogenetic results also agree with those of Hartman et al. ${ }^{58}$ in relating MPC-D 100/1128 and Liaoningvenator, but Almas (MPC-D 100/1323) is not recovered as a member of this sub-family, unlike Turner's results ${ }^{23}$. In turn, Jinfengopteryginae is placed as the sister group of Sinovenatorinae and includes Jianinhualong, Mei, Sinovenator, and Xiaotingian. Despite some differences in the resulting topology, this relationship is similar to other previous phylogenetic results ${ }^{23,58}$. Perhaps, the most noticeable difference of our analyses is the location of Philovenator curriei as a jinfengopterygine; it is commonly considered the sister taxon of Linhevenator tani, and both are considered as derived troodontines ${ }^{49,55,59-61}$. Nevertheless, the recovery of Tamarro insperatus as a basal troodontid, most likely a jinfengopterygine, is in agreement with our anatomical comparisons.

Histology. Histological sectioning of the proximal shaft of MCD-7073 provides insights into the physiology of the new taxon. The cortex of the bone (133-185 $\mu \mathrm{m}$ thick) is primarily formed of primary lamellar and fibro-lamellar tissue, with predominantly longitudinal vascularity (Fig. 4A-C). A thin $(16 \mu \mathrm{m})$ avascular layer of endosteal lamellar bone encircles the medullary cavity (Fig. 4B,C). The inner cortex consists of compact coarse cancellous bone (CCCB) with large primary longitudinal vascular canals (original cancellous spaces) filled with lamellar bone deposits (Fig. 4B-D); the inner cortex displays more cancellous vacuities close to the medullary 


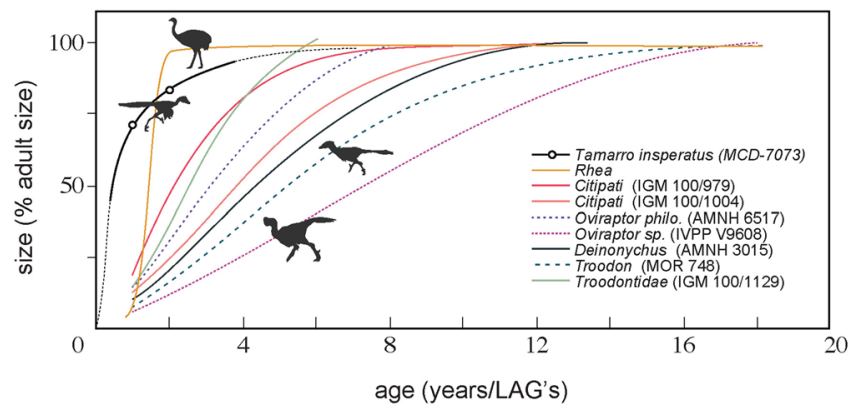

Figure 5. Growth curves of maniraptoran theropod dinosaurs. Tamarro insperatus outstands among other taxa for its fast initial growth, reaching subadulthood during the first year of life.

cavity. The outer cortex is of vascularized laminar fibrolamellar bone with relatively dense longitudinal canals of small size (Fig. 4E). The transition between the inner and the outer cortex is demarcated by a reversal line (Fig. 4E). One LAG is observed in the outermost part of the periosteal region (Fig. 4B). Neither secondary osteons nor an external fundamental system (EFS) are observed. It is worth mentioning the asymmetric development of the second growth cycle, which is more pronounced on the anterior and the lateral sides of the bone (Fig. 4F).

\section{Discussion}

The presence of troodontids in Europe has been debated for a long time, mainly because its record was entirely based on isolated teeth, until now. The oldest troodontid evidence in Europe dates back to the Early Cenomanian and is based on the discovery of one isolated tooth in western France ${ }^{62}$. Several troodontid-like and Paronychodon teeth (a nomen dubium taxa referred by some to Troodontidae ${ }^{63}$ were recovered from the Campanian and Maastrichtian deposits of the ancient Hateg (Romania) and Ibero-Armorican (Portugal, France, and Spain) islands ${ }^{8}$. In Romania, the enigmatic fossils of Bradycneme draculae and Elopteryx nopcsai were referred to Troodontidae ${ }^{63}$, although later works ruled out this assignment ${ }^{35,36}$. Similarly, Torices et al. ${ }^{64}$ questioned the attribution of Paronychodon teeth to troodontids. Consequently, the discovery of Tamarro insperatus in the latest Maastrichtian deposits from southern Pyrenees represents the first unequivocal bone evidence of this group of small-sized non-avian theropods in Europe, and confirms the occurrence of troodontids in the theropod faunal assemblage of that continent.

Ontogenetic stage, growth rate, and body size. According to the histological analysis, Tamarro insperatus shows some remarkable features among non-avian theropods. The primary bone of the specimen is mostly built on compact coarse cancellous and laminar fibrolamellar tissues with well-developed longitudinal vascularity, suggesting a high growth rate throughout ontogeny. This contrasts with the alternation of fibrolamellar and plexiform tissues observed in several coelurosaurians ${ }^{65-68}$. The occurrence of CCCB in Tamarro is likely because the histological sample was acquired near the proximal epiphysis of the bone ${ }^{69}$. The absence of EFS and Haversian structures suggests that Tamarro had not reached the somatic maturity at the time of its death. However, the occurrence of a well-developed endosteal lamina and the incorporation of compact coarse cancellous bone into the cortex indicate a mature stage of the individual and the cessation of the medullary expansion, and thus the attainment of subadult body size ${ }^{69}$. This interpretation is consistent with interweaving texture observed in the surface of the metatarsal II, a pattern associated with skeletal maturity in dinosaurs ${ }^{65,70,71}$.

Our osteohistological observations suggest that Tamarro attained subadult body size much earlier than other non-avian theropods ${ }^{67}$ by its fast growth rate in early ontogeny, but similar to extant palaeognathid birds (Fig. 5). Although troodontids are known to be fast-growing ${ }^{65,67}$, similar rapid initial growth rates without bone remodelling as that of Tamarro has only been reported in Mei long, which attained somatic maturity at only two years ${ }^{59}$. Liaoningvenator reached that stage in four years ${ }^{55}$; while derived troodontids required more time to achieve adulthood (5-9 years; Talos, Troodon $)^{48,72}$. In fact, the occurrence of laminar fibrolamellar tissues with welldeveloped longitudinal vascularity in Tamarro insperatus is more similar to the histological patterns of other basal troodontids (i.e. IGM 100/1129), than those of more derived ones (i.e. Troodon) $)^{73}$. If so, the histological evidence further supports our phylogenetic and anatomical results in interpreting Tamarro as a basal member of Troodontidae.

Troodontidae is a clade of small-bodied non-avian theropods that includes kiwi-size (i.e. $0.8 \mathrm{~kg}$ for Mei long) ${ }^{74}$ to rhea-size taxa (i.e. $47 \mathrm{~kg}$ for Troodon formosus) ${ }^{74}$. It is beyond the scope of this study to infer the full body size of Tamarro, but a preliminary approach can be performed by comparing the metatarsal II length among different troodontid taxa. The proximodistal length of metatarsal II of MCD-7073 was estimated at $140 \mathrm{~mm}$, which is about the same size as Gobivenator (145 mm; MPC-D 100/86), and roughly similar to Linhevenator (120 $\mathrm{mm} ; \mathrm{LH}$ V0021), Sinornithoides (100.5 mm; IVPP V9612) and Talos (159 mm; UMNH VP 19,479). However, it is more than the double of $\mathrm{Mei}(51 \mathrm{~mm}$; IVPP V12733), and nearly two times larger than its close phylogenetic relative (Fig. 2B and Table S2). If our phylogenetic interpretations are correct, Tamarro would be the largest, and one of the more derived jinfengopterygine yet discovered. 
Paleobiogeographic implications. Various biogeographic reviews on the Late Cretaceous faunas of Europe $^{8,75}$ underscored the likely presence of troodontids in the archipelago, based exclusively on teeth. Thus, in addition to the Campanian and Maastrichtian reports from Portugal, Romania, and Spain, an early occurrence of the group was reported from the Cenomanian of France ${ }^{62}$. The fragmentary and disparate fossil material of European troodontids prevents a clear correlation between the Cenomanian and Maastrichtian taxa, but the phylogenetic cluster in which Tamarro insperatus is included supports the idea that the clade migrated to Europe from Asia (Fig. 3A). The timing of such dispersal that brings the Maastrichtian troodontids to eastern (tooth evidence from Hateg island, Romania) and western Europe (Tamarro insperatus and tooth evidence from Ibero-Armorican island, Spain and Portugal) is, however, difficult to determine precisely. The Maastrichtian troodontids could have first reached Europe in the Cenomanian and persisted on the islands until the end of the Cretaceous; or alternatively, they could have arrived in the two migratory waves that brought Asian faunas to the archipelago. More particularly, this dispersal would have taken place during the Coniacian-Santonian or in a series of events that occurred around the Campanian-Maastrichtian boundary, most probably in the early Maastrichtian, a time when new immigrants triggered a dinosaur turnover in western Europe (Ibero-Armorican island $)^{8}$.

\section{Conclusions}

The discovery of the new basal troodontid Tamarro insperatus at the very end of the Cretaceous in Europe represents the first evidence of bones of Troodontidae in Europe. Both phylogenetic and osteohistological results support the basal nature of the new taxon, most likely as a representative of the Asian clade Jinfengopteryginae. The histological analysis also has provided evidence for a mature individual with a high growth rate, which allowed the animal to attain subadult body size in a very short time. This growth strategy is similar to other basal troodontids, such as the Asian Mei long.

The fragmentary, yet controversial, record of troodontid-like teeth from Europe together with the likely Asian affinity of Tamarro, confirm that troodontids could have reached the ancient European Archipelago during the Late Cretaceous. Furthermore, the relatively large size of Tamarro insperatus compared with its closest phylogenetic relatives suggests it would be the largest among jinfengopterygines.

\section{Methods}

Material and terminology. Right metatarsal II (MCD-7073), housed at the paleontological collection of the Museu de la Conca Dellà (MCD) in Isona, Pallars Jussà, Catalonia, southern Pyrenees. The director of MCD, A.G.-which is also a co-author of the present study - granted access to the collection under his care and provided permission the study and graphic reproduction of the specimen.

Thin section and histological analyses. A histological sample was taken from the proximal region of the shaft of the Mt II. The samples were exposed using a Buehler Isomet low-speed saw and subsequently polished on a glass sheet coated with carborundum powder, using decreasing particle sizes of 600, 800, and 1000 grit. The bone sample was fixed to a frosted glass slide using ultraviolet curing glue Loctite 358 . The ground section was then prepared with a diamond saw (Buehler, PetroThin) to a final thickness of approximately $60 \mu \mathrm{m}$. The slice was dehydrated through a graded series of alcohol baths, cleared in Histo-Clear II for five minutes, and finally mounted in a DPX mounting medium. The thin section was observed under transmitted and polarized light using a petrographic microscope Nikon Eclipse E400 POL connected to a digital camera Nikon DS-FI3.

Phylogenetic analyses. In order to establish the phylogenetic relationships of Tamarro insperatus, phylogenetic analysis of the new taxon was added to the large-scale theropod analysis of Hartman et al..$^{58}$. MCD-7073 was coded using Mesquite $3.61^{76}$, comprising 502 species-level theropod taxa and 700 morphological characters, and analysed using TNT $1.1^{77}$ to find the most parsimonious trees (MPTs). For our exploration, we set the maximum tree saved in memory at 10,000 and used a traditional search, performing 10,000 replications of Wagner trees (using random addition sequences) followed by tree bisection reconnection (TBR) as swapping algorithm, saving 10 trees per replicate.

All figures, silhouettes, and drawings that accompany this study were created by the authors using Adobe Illustrator CC 20152.1.

Received: 29 July 2020; Accepted: 4 February 2021

Published online: 01 March 2021

\section{References}

1. Nopcsa, F. Über das Vorkommen der Dinosaurier in Siebenbürgen. Verhandlungen Zoologische-botanischen Gesellschaft Wien 54, 12-14 (1914).

2. Weishampel, D. B., Grigorescu, D. \& Norman, D. B. The dinosaurs of Transylvania. Nat. Geogr. Res. 7, 196-215 (1991).

3. Benton, M. et al. Dinosaurs and the island rule: The dwarfed dinosaurs from Haţeg Island Palaeogeo. Palaeoclim. Palaeoecol. 29, 438-454 (2010).

4. Stein, K. et al. Small body size and extreme cortical bone remodelling indicate phyletic dwarfism in Magyarosaurus dacus (Sauropoda:Titanosauria). PNAS 107, 9258-9263 (2010).

5. Csiki, Z., Vremir, M., Brusatte, S. L. \& Norell, M. A. An aberrant island-dwelling theropod dinosaur from the Late Cretaceous of Romania. PNAS 107, 15357-15361 (2010).

6. Brusatte, S. L., Vremir, M., Csiki-Sava, Z., Turner, A. H. \& Watanabe, A. The osteology of Balaur bondoc, an island-dwelling dromaeosaurid (Dinosauria: Theropoda) from the Late Cretaceous of Romania. Bull. Am. Mus. Nat. Hist. 374, 1-100 (2013). 
7. Csiki-Sava, Z., Vremir, M., Meng, J., Brusatte, S. L. \& Norell, M. A. Dome-headed, small-brained island mammal from the Late Cretaceous of Romania. PNAS 8, 4857-4862 (2018).

8. Csiki-Sava, Z., Buffetaut, E., Ösi, A., Pereda-Suberbiola, X. \& Brusatte, S. L. Island life in the Cretaceous-faunal composition, biogeography, evolution, and extinction of land-living vertebrates on the Late Cretaceous European archipelago. ZooKeys 469, $1-161$ (2015).

9. Vila, B., Sellés, A. G. \& Brusatte, S. L. Diversity and faunal changes in the latest Cretaceous dinosaur communities of south-western Europe. Cret. Res. 57, 552-564 (2016).

10. Chiarenza, A. A. et al. Ecological niche modelling does not support climatically-driven dinosaur diversity decline before the Cretaceous/Paleogene mass extinction. Nat. Commun. 10, 1091 (2019).

11. Brusatte, S. L. et al. The extinction of the dinosaurs. Biol. Rev. 90, 628-642 (2015).

12. Witton, M. P. \& Naish, D. A reappraisal of azhdarchid pterosaur functional morphology and paleoecology. PLoS ONE 3, e2271 (2008).

13. Zanno, L. E. \& Makovicky, P. J. Herbivorous ecomorphology and specialization patterns in theropod dinosaur evolution. PNAS 108, 232-237 (2011).

14. Torices, A., Currie, P. J., Canudo, J. I. \& Pereda-Suberbiola, X. Theropod dinosaurs from the Upper Cretaceous of the South Pyrenees Basin of Spain. Acta Palaeontol. Pol. 60, 611-626 (2015).

15. Fondevilla, V. et al. Chronostratigraphic synthesis of the latest Cretaceous dinosaur turnover in South-Western Europe. Earth https://doi.org/10.1016/j.earscirev.2019.01.007 (2019).

16. Sellés, A. G., Vila, B. \& Galobart, À. Diversity of theropod ootaxa and its implications for the latest Cretaceous dinosaur turnover in south-western Europe. Cret. Res. 49, 45-54 (2014).

17. Vila, B., Sellés, A. G. \& Beetschen, J. C. The controversial Les Labadous eggshells: A new and peculiar dromaeosaurid (Dinosauria: Theropoda) ootype from the Upper Cretaceous of Europe. Cret. Res. 72, 117-123 (2017).

18. Le Loeuff, J., Buffetaut, E., Mechin, P. \& Mechin-Salessy, A. The first record of dromaeosaurid dinosaurs (Saurischia, Theropoda) in the Maastrichtian of southern Europe: Paleobiogeographical implications. Bull. Soci. Géol. France 163, 337-343 (1992).

19. Buffetaut, E. et al. An early Campanian vertebrate fauna from the Villeveyrac Basin (Hérault, southern France). Neues Jahrb. Geol. P-A. 1996, 1-16 (1996).

20. Le Loeuff, J. \& Buffetaut, E. A new dromaeosaurid theropod from the Upper Cretaceous of southern France. Oryctos 1, 105-112 (1998).

21. Chanthasit, P. \& Buffetaut, E. New data on the Dromaeosauridae (Dinosauria: Theropoda) from the Late Cretaceous of southern France. Bull. Soci. Géol. France 180, 145-154 (2009).

22. Allain, R. \& Taquet, P. A new genus of Dromaeosauridae (Dinosauria, Theropoda) from the Upper Cretaceous of France. J. Vert. Paleontol. 20, 404-407 (2000).

23. Turner, A. H., Makovicky, P. J. \& Norell, M. A. A review of dromaeosaurid systematics and paravian phylogeny. Bull. Am. Mus. Nat. Hist. 371, 1-206 (2012).

24. Barrera, E. Global environmental changes preceding the Cretaceous-Tertiary boundary: Early-late Maastrichtian transition. Geology 22, 877-880 (1994).

25. Barrera, E. \& Savin, S. M. Evolution of late Campanian-Maastrichtian marine climates and oceans. In Evolution of the Cretaceous Ocean-Climate System (eds Barrera, E. \& Johnson, C. C.) 245-282 (Geological Society of America, Boulder, 1999).

26. Miller, K. G. et al. The Phanerozoic record of global sea-level change. Science 310, 1293-1298 (2005).

27. Voigt, S., Gale, A. S., Jung, C. \& Jenkyns, H. C. Global correlation of Upper Campanian-Maastrichtian successions using carbonisotope stratigraphy: development of a new Maastrichtian timescale. Newsl. Stratigr. 45, 25-53 (2012).

28. Linnert, C. et al. Did Late Cretaceous cooling trigger the Campanian-Maastrichtian Boundary Event?. Newsl. Stratigr. 51, 145-166 (2018).

29. Le Loeuff, J., Buffetaut, E. \& Martin, M. The last stages of dinosaur faunal history in Europe: A succession of Maastrichtian dinosaur assemblages from the Corbières (southern France). Geol. Mag. 131, 625-630 (1994).

30. Riera, V., Oms, O., Gaete, R. \& Galobart, À. The end-Cretaceous dinosaur succession in Europe: The Tremp Basin record (Spain). Palaeogeo. Palaeoclim. Palaeoecol. 283, 160-171 (2009).

31. Casanovas, M. L., Santafé-Llopis, J. V. \& Isidro-Llorens, A. Pararhabdodon isonense n. gen. n. sp. (Dinosauria). Estudio morfológico, radiotomográfico y consideraciones biomecánicas. Paleontol. Evol. 26-27, 121-131 (1993).

32. Prieto-Márquez, A., Dalla Vecchia, F. M., Gaete, R. \& Galobart, À. Diversity, relationships, and biogeography of the lambeosaurine dinosaurs from the European archipelago, with description of the new aralosaurin Canardia garonnensis. PLoS ONE 8, e69835 (2013).

33. Serrano, J. F., Sellés, A. G., Vila, B., Galobart, À. \& Prieto-Márquez, A. The osteohistology of new remains of Pararhabdodon isonensis sheds light into the life history and paleoecology of this enigmatic European lambeosaurine dinosaur. Cret. Res. https:// doi.org/10.1016/j.cretres.2020.104677 (2020).

34. Andrews, C. W. On some bird remains from the Upper Cretaceous of Transylvania. Geol. Mag. 10, 193-196 (1913).

35. Kessler, E., Grigorescu, D. \& Csiki, Z. Elopteryx revisited: A new bird-like specimen from the Maastrichtian of the Haţeg Basin (Romania). Acta. Palaeontol. Roman. 5, 249-258 (2005).

36. Naish, D. \& Dyke, G. J. Heptasteornis was no ornithomimid, troodontid, dromaeosaurid or owl: The first alvarezsaurid (Dinosauria: Theropoda) from Europe. Neues. Jahrbuch. Geol. Paläontol. Monatshefte 2004, 385-401 (2004).

37. Harrison, C. J. O. \& Walker, C. A. The Bradycnemidae, a new family of owls from the Upper Cretaceous of Romania. Palaeontol. 18, 563-570 (1975).

38. Case, J. A., Martin, J. E. \& Reguero, M. A dromaeosaur from the Maastrichtian of James Ross Island and the Late Cretaceous Antarctic dinosaur fauna. Antarctica 083, 4. https://doi.org/10.3133/of2007-1047 (2007).

39. Ely, R. C. \& Case, J. A. Phylogeny of a new gigantic paravian (Theropoda; Coelurosauria; Maniraptora) from the Upper Cretaceous of James Ross Island, Antarctica. Cret. Res. 101, 1-16 (2019).

40. Novas, F. E. \& Pol, D. New evidence on deinonychosaurian dinosaurs from the Late Cretaceous of Patagonia. Nature 433, 858-861 (2005).

41. Xu, X. \& Qin, Z.-C. A new tiny dromaeosaurid dinosaur from the Lower Cretaceous Jehol Group of western Liaoning and niche differentiation among the Jehol dromaeosaurids. Vert. PalAs. 4, 129-144 (2017).

42. Cau, A., Brougham, T. \& Naish, D. The phylogenetic affinities of the bizarre Late Cretaceous Romanian theropod Balaur bondoc (Dinosauria, Maniraptora): Dromaeosaurid or flightless bird?. PeerJ 3, e1032 (2015).

43. White, M. A. The subarctometatarsus: Intermediate metatarsus architecture demonstrating the evolution of the arctometatarsus and advanced agility in theropod dinosaurs. Alcheringa 33, 1-21 (2009).

44. Tsuihiji, T. et al. New material of a troodontid theropod (Dinosauria: Saurischia) from the Lower Cretaceous of Mongolia. Hist. Biol. 28, 128-138 (2016).

45. Funston, G. F. Caenagnathids of the Dinosaur Park Formation (Campanian) of Alberta, Canada: Anatomy, osteohistology, taxonomy, and evolution. Vert. Anat. Morphol. Palaeontol. 8, 105-153 (2020).

46. Holtz, T. R. Jr. The arctometatarsalian pes, an unusual structure of the metatarsus of Cretaceous Theropoda (Dinosauria: Saurischia). J. Vert. Paleontol. 14, 480-519 (1995). 
47. Snively, E., Russell, A. P. \& Powel, G. L. Evolutionary morphology of the coelurosaurian arctometatarsus: Descriptive, morphometric and phylogenetic approaches. Zool. J. Linn. Soc. 142, 525-553 (2004).

48. Zanno, L. E., Varricchio, D. J., O’Connor, P. M., Titus, A. L. \& Knell, M. J. A New troodontid theropod, Talos sampsoni gen. et. sp. nov., from the Upper Cretaceous Western Interior Basin of North America. PLoS ONE 6, e24487 (2011).

49. van der Ress, A. J. \& Currie, P. Troodontids (Theropoda) from the Dinosaur Park Formation, Alberta, with a description of a unique new taxon: implications for deinonychosaur diversity in North America. Can. J. Earth Sci. 54, 919-935 (2017).

50. Xu, X. et al. The taxonomy of the troodontid IVPP V 10597 reconsidered. Vert. PalAs. 4, 140-150 (2012).

51. Xu, L. et al. A new ornithomimid dinosaur with North American affinities from the Late Cretaceous Qiupa Formation in Henan Province of China. Cret. Res. 32, 213-222 (2011).

52. Tsogtbaatar, C. et al. First ornithomimid (Theropoda, Ornithomimosauria) from the Upper Cretaceous Djadokhta Formation of Tögrögiin Shiree, Mongolia. Sci. Rep. 7, 5835 (2016).

53. Claessens, L. P. A. M. \& Loewen, M. A. A redescription of Ornithomimus velox Marsh, 1890 (Dinosauria, Theropoda). J. Vert. Paleontol. 36, e1034593 (2015).

54. Funston, G. F., Currie, P. J., Ryan, M. J. \& Dong, Z.-M. Birdlike growth and mixed-age flocks in avimimids (Theropoda, Oviraptorosauria). Sci. Rep. 9, 18816 (2019).

55. Shen, C., Zhao, B., Gao, C., Lü, J. \& Kundrát, M. A new troodontid dinosaur (Liaoningvenator curriei gen. et. sp. nov.) from the Early Cretaceous Yixian Formation in Western Liaoning Province. Vert. PalAs. 3, 359-371 (2017).

56. Shen, C. et al. A new troodontid Dinosaur from the Lower Cretaceous Yixian Formation of Liaoning Province, China. Acta Geol. Sin. 91, 763-780 (2017).

57. Currie, P. J. \& Peng, J. A juvenile specimen of Saurornithoides mongoliensis from the Upper Cretaceous of northern China. Can. J. Earth Sci. 30, 2224-2230 (1993).

58. Hartman, S. et al. A new paravian dinosaur from the Late Jurassic of North America supports a late acquisition of avian flight. PeerJ 7, e7247 (2019)

59. Gao, C., Morschhauser, E. M., Varricchio, D. J., Liu, J. \& Zhao, B. A. Second soundly sleeping dragon: New anatomical details of the Chinese troodontid Mei long with Implications for phylogeny and taphonomy. PLoS ONE 7, e45203 (2012).

60. Averianov, A. \& Sues, H.-D. Troodontidae (Dinosauria: Theropoda) from the Upper Cretaceous of Uzbekistan. Cret. Res. 59, 98-110 (2016).

61. Tsuihiji, T. et al. An exquisitely preserved troodontid theropod with new information on the palatal structure from the Upper Cretaceous of Mongolia. Naturwissenschaften https://doi.org/10.1007/s00114-014-1143-9 (2014).

62. Vullo, R., Néraudeau, D. \& Lenglet, T. Dinosaur teeth from the Cenomanian of Charentes, Western France: Evidence for a mixed Laurasian-Gondwanan assemblage. J. Vertebr. Paleontol. 27, 931-943 (2007)

63. Makovicky, P. J. \& Norell, M. A. Troodontidea. In The Dinosauria (eds Weishampel, D. et al.) $184-195$ (University of California Press, California, 2004).

64. Torices, A., Currie, P. J., Canudo, J. I. \& Pereda-Suberbiola, X. Theropod dinosaurs from the Upper Cretaceous of the South Pyrenees Basin of Spain. Act. Paleontol. Pol. 60, 611-626 (2015).

65. Erickson, G. M., Curry Rogers, K. \& Yerby, S. A. Dinosaurian growth patterns and rapid avian growth rates. Nature 412, 429-433 (2001).

66. Cullen, T. M., Simon, D. J., Benner, E. K. C. \& Evans, D. C. Morphology and osteohistology of a large-bodied caenagnathid (Theropoda, Oviraptorosauria) from the Hell Creek Formation (Montana): Implications for size-based classifications and growth reconstruction in theropods. Pap. Palaeontol. https://doi.org/10.1002/spp2.1302 (2020).

67. Erickson, G. M., Curry Rogers, K., Varricchio, D. J., Norell, M. A. \& Xu, X. Growth patterns in brooding dinosaurs reveals the timing of sexual maturity in non-avian dinosaurs and genesis of the avian condition. Biol. Lett. 3, 558-561 (2007).

68. Skutschas, P. P., Boitsova, E. A., Averianov, A. O. \& Sues, H.-D. Ontogenetic changes in long-bone histology of an ornithomimid theropod dinosaur from the Upper Cretaceous Bissekty Formation of Uzbekistan. Hist. Biol. 29, 6. https://doi.org/10.1080/08912 963.2016.1233180 (2017).

69. Chinsamy-Turan, A. The Microstructure of Dinosaur Bone: Deciphering Biology with Fine Scale Techniques (Johns Hopkins. University Press, Baltimore, 2005).

70. Sampson, S. D., Ryan, M. J. \& Tanke, D. H. Craniofacial ontogeny in centrosaurine dinosaurs (Ornithischia: Ceratopsidae): taxonomic and behavioral implications. Zool. J. Linn. Soc. 121, 293-337 (1997).

71. Loewen, M. A. Variation in the Late Jurassic theropod dinosaur Allosaurus: ontogenetic, functional, and taxonomic implications. Ph.D. University of Utah, Salt Lake City, Utah 326 (2009).

72. Varricchio, D. et al. Avian paternal care had dinosaur origin. Science 322, 1826-1828 (2009).

73. Erickson, G. M. et al. Was dinosaurian physiology inherited by birds? Reconciling slow growth in Archaeopteryx. PLoS ONE 4, e7390 (2009).

74. Benson, R. B. J. et al. Rates of dinosaur body mass evolution indicate 170 million years of sustained ecological Innovation on the avian stem lineage. PLoS Biol. 12, e1001853 (2014).

75. Pereda-Suberbiola, X. Affinités paléobiogéographiques des tétrapodes continentaux du Crétacé supérieur d'Europe: une mise au point. Bull. Soc. Geol. Franc. 180, 57 (2009).

76. Maddison, W. P. \& Maddison, D. R. Mesquite: A Modular System for Evolutionary Analysis. Version 3.61. http://www.mesquitepr oject.org (2019).

77. Goloboff, P. A., Farris, J. S. \& Nixon, K. C. TNT, a free program for phylogenetic analysis. Cladistics 24, 774-786 (2008).

\section{Acknowledgements}

This work has been supported by the Spanish Agencia Estatal de Investigación (CGL2016-76431-P, CGL201673230-P, and CGL2017-82654-P) and the Generalitat de Catalunya (CERCA Program). Osteohistological analysis were partially supported by the project "Xarxes paleocològiques dels jaciments de dinosaures del Cretaci català" ("Paleoecological networks of the dinosaur quarries of the Catalan Cretaceous") CLT/903/2018/67, funded by the Departament de Cultura of the Generalitat de Catalunya. Additional support was also provided by the CERCA Programme of the Generalitat de Catalunya. A.G.S., B.V., and À.G. are part of the consolidated research group 2017 SGR 01666 of the Agència de Gestió i Ajuts Universitaris i de Recerca (AGAUR). We further acknowledge the collaboration of the Servei d'Arqueologia i Paleontologia of the Generalitat de Catalunya. Special thanks to the field team that excavated the SRA site in September 2003.

\section{Author contributions}

A.G.S. and B.V. designed and conducted the study; A.G.S., B.V., S.L.B., and P.J.C. collected data; A.G.S., B.V., S.L.B. and P.J.C. analyzed data; A.G.S., B.V., S.L.B., and P.J.C. interpreted data. À.G. directed fieldwork and obtained funding; A.G.S., B.V., and S.L.B. wrote the paper, with input from all co-authors. 


\section{Competing interests}

The authors declare no competing interests.

\section{Additional information}

Supplementary Information The online version contains supplementary material available at https:/doi. org/10.1038/s41598-021-83745-5.

Correspondence and requests for materials should be addressed to A.G.S.

Reprints and permissions information is available at www.nature.com/reprints.

Publisher's note Springer Nature remains neutral with regard to jurisdictional claims in published maps and institutional affiliations.

(c) (1) Open Access This article is licensed under a Creative Commons Attribution 4.0 International License, which permits use, sharing, adaptation, distribution and reproduction in any medium or format, as long as you give appropriate credit to the original author(s) and the source, provide a link to the Creative Commons licence, and indicate if changes were made. The images or other third party material in this article are included in the article's Creative Commons licence, unless indicated otherwise in a credit line to the material. If material is not included in the article's Creative Commons licence and your intended use is not permitted by statutory regulation or exceeds the permitted use, you will need to obtain permission directly from the copyright holder. To view a copy of this licence, visit http://creativecommons.org/licenses/by/4.0/.

(C) The Author(s) 2021 